\title{
ANALISIS KEUNTUNGAN USAHA TEMPE SUMARKO DI KELURAHAN TELING ATAS KECAMATAN WANEA KOTA MANADO
}

\author{
Winda Lita Theresia Porajouw \\ Joachim Noch Karel Dumais \\ Yolanda Pinky Ivanna Rori
}

\begin{tabular}{ll}
\hline Naskah diterima melalui email dari Jurnal Ilmiah agrisosioekonomi@unsrat.ac.id & : Sabtu, 20 April 2019 \\
Disetujui diterbitkan & : Rabu, 24 April 2019 \\
\hline
\end{tabular}

\begin{abstract}
The objective of this research is to analyze the profit of Tempe Sumarko Business in Teling Atas Village, Wanea Subdistrict Manado City. This research was conducted for 3 months, starting from January to March 2019. The data used in this research are primary data and secondary data. Primary data was obtained from a direct interview with the owner of Tempe Sumarko Business. While secondary data was obtained from books available at local bookstores and the internet such as google searching to access articles from various scientific journals and thesis from other universities related to the topic of this research, especially concerning profit analysis. The results of the research indicated that Tempe Sumarko Business is profitable. The profit in December 2018 was Rp. 3.746.432,78 with the value of R/C ratio >1 which was 1,24 and the profit in January 2019 was $R p .5 .216 .432,78$ with the value of $R / C$ ratio which was 1,35 . ${ }^{*}$ nkd+erprm*
\end{abstract}

Keywords: profit, tempe, Sumarko, Manado City

\section{ABSTRAK}

Tujuan penelitian ini adalah untuk menganalisis keuntungan dari usaha tempe Sumarko di Desa Teling Atas Kecamatan Wanea Kota Manado. Penelitian ini dilaksanakan selama 3 bulan, mulai dari bulan Januari sampai Maret 2019. Data yang digunakan dalam penelitian ini adalah data primer dan data sekunder. Data primer diperoleh dari wawancara langsung kepada pemilik usaha tempe Sumarko. Sedangkan data sekunder diperoleh dari buku-buku yang tersedia di toko buku lokal dan internet seperti pencarian google untuk mengakses artikel dari berbagai jurnal ilmiah dan skripsi dari perguruan tinggi lain yang berkaitan dengan topik penelitian ini terutama menyangkut analisis keuntungan. Hasil dari penelitian ini mengindikasi bahwa usaha tempe Sumarko menguntungkan. Keuntungan bulan Desember 2018 sebesar Rp. 3.746.432,78 dengan nilai R/C ratio sebesar 1,24 dan keuntungan bulan Januari 2019 sebesar Rp. 5.216.432,78 dengan nilai R/C sebesar 1,35. ${ }^{*}$ jnkd+erprm*

Kata kunci: keuntungan, tempe, Sumarko, Kota Manado

\section{PENDAHULUAN}

\section{Latar Belakang}

Sektor industri pengolahan merupakan salah satu penyumbang dalam memantapkan perekonomian di Indonesia. Industri pengolahan pangan merupakan industri yang bergerak dalam pengolahan hasil pertanian, baik nabati maupun hewani menjadi produk pangan olahan, yang dapat dibuat dan dikembangkan dari sumber daya alam lokal (Soleh dalam Sarfan, 2016).
Industri pertanian dikenal dengan nama agroindustri, dimana agroindustri merupakan kegiatan industri yang memanfaatkan hasil pertanian sebagai bahan baku, merancang dan menyediakan peralatan serta jasa untuk kegiatan tersebut. Agroindustri merupakan bagian (subsistem) agribisnis yang memproses dan mentranformasikan bahan-bahan hasil pertanian (bahan makanan, kayu dan serat) menjadi barang-barang setengah jadi yang langsung dapat dikonsumsi dan barang atau bahan hasil produksi industri yang digunakan dalam proses 
produksi seperti traktor, pupuk, pestisida, mesin pertanian dan lain-lain (Udayana, 2011).

Di Indonesia, kedelai merupakan komoditas terpenting ketiga setelah padi dan jagung. Lebih dari 90 persen kedelai Indonesia digunakan sebagai bahan pangan, terutama pangan olahan, yaitu sekitar 88 persen untuk tahu dan tempe, 10 persen untuk pangan olahan lainnya dan sekitar 2 persen untuk benih (Sudaryanto dan Swastika, 2007).

Salah satu hasil olahan yang menggunakan kedelai sebagai bahan baku adalah tempe. Tempe diminati oleh masyarakat, selain harganya murah, juga memiliki kandungan protein nabati yang tinggi. Usaha pengolahan tempe yang sebagian besar berskala industri rumah tangga banyak di geluti oleh masyarakat Indonesia di berbagai daerah.

Tempe Sumarko merupakan salah satu industri rumah tangga yang menggunakan kedelai sebagai bahan baku pembuatan tempe. Usaha Tempe Sumarko terletak di Teling Atas Kecamatan Wanea Kota Manado.

Usaha rumah tangga tempe Sumarko telah berjalan selama kurang lebih 48 tahun dan sampai saat ini masih bertahan dan memberikan keuntungan kepada pengusaha selain untuk kebutuhan konsumsi keluarga tetapi juga untuk kontinuitas usaha tempe. Usaha ini relatif stabil karena banyaknya tempe yang diproduksi setiap hari relatif sama setiap satu kali proses produksi namun hasil produksi yang dijual sebagian besar dijual pada pelanggan tetap sehingga jangkauan pasar untuk usaha ini masih kurang besar. Usaha yang telah beroperasi selama puluhan tahun ini belum memiliki izin usaha serta label sehingga produk tempe yang dihasilkan masih belum bisa dipasarkan di supermarket.

\section{Perumusan Masalah}

Berdasarkan latar belakang yang telah dikemukakan, maka yang menjadi permasalahan yang akan dikaji dalam penelitian ini adalah berapa besar keuntungan dari usaha tempe Sumarko di Teling Atas Kecamatan Wanea Kota Manado.

\section{Tujuan Penelitian}

Adapun tujuan dari penelitian ini adalah untuk mengkaji keuntungan dari usaha Tempe Sumarko di Teling Atas Kecamatan Wanea Kota Manado.

\section{Manfaat Penelitian}

Ada beberapa manfaat yang dapat diperoleh dari penulisan ilmiah ini, seperti:

1. Bagi peneliti, penelitian ini sebagai salah satu karya ilmiah untuk mengembangkan pengetahuan dan wawasan mengenai industri rumah tangga tempe.

2. Bagi pihak Tempe Sumarko, dapat menjadi bahan masukan yang bermanfaat untuk meningkatkan keuntungan dalam berusaha.

3. Bagi pihak lain, diharapkan dapat menambahkan wawasan dan pengetahuan serta dapat dijadikan acuan dan informasi untuk penelitian selanjutnya.

\section{METODE PENELITIAN}

\section{Tempat dan Waktu Penelitian}

Penelitian ini dilakukan selama 3 bulan mulai dari tahap persiapan hingga penyusunan laporan yakni di mulai bulan Januari 2019 sampai bulan Maret 2019. Penelitian dilaksanakan di Kelurahan Teling Atas Kecamatan Wanea Kota Manado.

\section{Metode Pengumpulan Data}

Data yang digunakan dalam penelitian ini adalah data primer Data primer merupakan data yang diperoleh peneliti di lapangan langsung dari sumbernya yaitu dalam penelitian ini adalah pemillik usaha Tempe Sumarko.

Teknik pengumpulan data yang digunakan dalam penelitian ini adalah :

1) Observasi

2) Wawancara

\section{Harga (Rp)}

\section{Konsep Pengukuran Variabel}

Harga jual produk tempe yang dihasilkan sesuai dengan ukuran yang ada

2. Produksi (Bungkus)

Jumlah produksi tempe yang dihasilkan dalam satu bulan produksi

3. Biaya Produksi (Rp)

Besar biaya yang dikeluarkan dalam pembuatan tempe setiap kali produksi perbulan yang terdiri dari :

a. Biaya Tetap
- Biaya Listrik (Rp)
Biaya yang dikeluarkan untuk membayar listrik perbulan 
- Biaya Penyusutan Alat (Rp)

Menurut Kuswadi (2006) dalam Wardani (2008) untuk menghitung besar biaya penyusutan peralatan dengan menggunakan metode garis lurus dengan rumus sebagai berikut:

Biaya Penyusutan Alat $=\frac{\text { Nilai Investasi Awal }- \text { Nilai Investasi Akhir }}{\text { Umer Ekonis(bun) }}$

- Biaya Sewa Tempat Usaha (Rp)

Biaya per bulan yang bayarkan untuk menyewa tempat usaha

- Biaya Bunga Modal (Rp)

Biaya bunga per bulan dari modal yang di pinjam

b. Biaya Variabel

- Biaya Transportasi (Rp)

Biaya perbulan yang digunakan untuk memasarkan tempe diluar tempat usaha

- Biaya Bahan Baku (Rp)

Bahan baku utama yaitu kedelai yang dipakai dalam proses produksi perbulan

- Biaya Bahan Penolong (Rp)

Bahan penolong yang digunakan adalah terigu dan ragi dalam proses produksi perbulan

- Biaya Bahan Bakar (Rp)

Biaya perbulan yang digunakan untuk membeli bahan bakar yaitu kayu bakar

- Biaya Pengemasan (Rp)

Terdiri dari biaya plastik kemasan dan daun dalam satu bulan

- Biaya Tenaga Kerja (Rp)

Upah tenaga kerja yang dibayarkan perbulan

c. Biaya Total (Rp)

Biaya tetap ditambah biaya variabel dalam satu bulan.

4. Penerimaan (Rp)

Jumlah produksi dalam satu bulan dikalikan dengan harga yang berlaku.

5. Keuntungan (Rp)

Selisih antara jumlah penerimaan dalam satu bulan dan biaya total yang dikeluarkan dalam satu bulan.

\section{Metode Analisis Data}

Data yang dikumpulkan kemudian dianalisis menggunakan analisis keuntungan yaitu dengan menghitung selisih antara penerimaan dengan biaya yang digunakan kemudian di lanjutkan dengan rumus Analisis Revenue Cost Ratio.

\section{HASIL DAN PEMBAHASAN}

\section{Deskripsi Umum Usaha Tempe Sumarko}

Usaha tempe ini berdiri sejak tahun 1971 yang dikelola oleh orangtua Bapak Sumarko, sebelumya orangtua Bapak Sumarko bekerja sebagai petani ketika datang merantau ke Manado dan menanam kedelai, jagung serta padi. Pada akhir tahun 1980-an usaha tempe diteruskan oleh Bapak Sumarko. Awalnya rumah yang digunakan untuk proses produksi hanyalah rumah sewa hingga akhirnya pada tahun 1991 Bapak Sumarko telah memiliki rumah sendiri, selain untuk menjadi tempat tinggal bersama keluarga tetapi juga untuk dijadikan tempat produksi dari usaha tempe. Usaha tempe Bapak Sumarko ini bertempat di Jalan 11 Februari, Lingkungan II, Kelurahan Teling Atas Kecamatan Wanea Kota Manado.

Sebelumnya pembelian bahan baku kedelai usaha ini sebesar sepuluh sampai lima belas karung dengan skala produksi satu hari sebanyak 20 kilogram sehingga 1 karung bisa digunakan untuk proses produksi 2 hari, tetapi terjadi peningkatan pembelian pada tahun 1994 yaitu 1 ton atau setara dengan 20 karung dengan skala produksi yang meningkat sebanyak 50 kilogram atau 1 karung dalam satu hari proses produksi.

Proses produksi tempe Sumarko masih menggunakan cara tradisional dan semuanya dilakukan dengan manual tanpa bantuan mesin. Usaha ini berproduksi setiap hari dengan jam operasional selama \pm 8 jam per hari. Proses produksi dimulai dari jam 06.00 sampai 14.00 , belum termasuk dengan proses perebusan bahan baku kedelai.

Hasil keuntungan dari usaha tempe diakui pemilik mampu untuk memenuhi kebutuhan pangan (konsumsi sehari-hari) keluarga, membiayai sekolah anak serta cucu, modal untuk kesinambungan usaha serta hasil yang didapatkan ditabung untuk kebutuhan keluarga kedepan.

Tempe Sumarko pada tahun 1970-an telah mendapat izin berusaha namun tidak sempat diperpanjang, dimana perpanjangan dilakukan setiap lima tahun. Saat ini pemilik usaha sedang berupaya untuk mendapatkan izin usaha serta label untuk tempe. 
Tempe telah dibawa ke laboratorium untuk pemeriksaan nutrisi dan kebersihan dengan mendapatkan hasil yang bagus dan sekarang masih dalam proses menunggu penyuluhan dari Badan Perindustrian, dimana menunggu slot untuk pengusaha yang mendaftarkan usahanya mencapai 20 usaha.

\section{Proses Produksi Tempe}

Proses produksi tempe Sumarko dimulai dengan menuangkan kedelai dari karung kedalam air dan dibersihkan dari kotoran yang terdapat diantara kedelai kemudian direbus dengan api kecil selama \pm 2 jam. Setelah itu kedelai diangkat dan dinginkan sehingga proses pemisahan kulit ari dapat dimulai. Proses ini bertujuan untuk memisahkan kedelai dari kulit arinya dan untuk mengetahui apakah tekstur dari kedelai sudah tepat sesuai keinginan dari Bapak Sumarko. Pemisahan kulit ari dilakukan secara manual dengan cara diremas menggunakan tangan. Setelah itu kedelai dicuci dan direndam selama satu malam. Pada besok paginya kedelai dikukus setelah itu kedelai diangkat dan didinginkan menggunakan kipas angin selama dua sampai tiga jam. Ketika kedelai sudah dingin dicampurkan tepung beras putih dan ragi tempe. Banyaknya pemakaian ragi tempe tergantung pada musim. Ketika musim hujan dimana udara menjadi agak lembab maka diperlukan banyak ragi tempe agak proses fermentasi dapat berhasil dengan baik kemudian ketika musim panas dimana udara akan panas maka ragi tempe yang diperlukan tidak terlalu banyak karena bakteri untuk fermentasi dapat bekerja lebih baik pada waktu musim panas. Setelah itu campuran itu dikemas sesuai dengan ukuran. Setelah dikemas, tempe didiamkan untuk proses fermentasi. Proses produksi berlangsung selama tiga sampai empat hari dari proses perebusan hingga proses fermentasi.

\section{Jenis Produk}

Usaha tempe Sumarko memiliki empat jenis ukuran tempe yang diperjualbelikan. Ukuran lebar memiliki panjang $11,5 \mathrm{~cm}$ dan lebar $8,5 \mathrm{~cm}$, ukuran panjang memiliki panjang $14,5 \mathrm{~cm}$ dan lebar $6,5 \mathrm{~cm}$, ukuran kecil memiliki panjang $11,5 \mathrm{~cm}$ dan lebar $5,5 \mathrm{~cm}$ dengan ketebalan masing-masing sebesar 1,5 $\mathrm{cm}$ serta ukuran bulat berdiameter $4,5 \mathrm{~cm}$ dengan panjang $15 \mathrm{~cm}$.

\section{Jumlah Produksi}

Dalam satu kali proses produksi usaha ini bisa menghasilkan \pm 700 bungkus tempe sehingga dalam satu bulan bisa menghasilkan \pm 21.000 bungkus tempe. Banyaknya produksi dalam satu bulan bisa berkurang ketika usaha tempe tidak melakukan proses produksi dan hal itu terjadi pada perayaan hari raya-hari raya besar.

Pada saat Idul Fitri tidak berproduksi selama satu minggu sedangkan pada Hari Raya Qurban dan Hari Raya Natal tidak berproduksi selama satu hari dan pada saat Tahun Baru tidak berproduksi selama dua hari.

Jumlah produksi tempe untuk setiap ukuran pada bulan Desember 2018 dan Januari 2019 dapat dilihat pada Tabel 1.

\begin{tabular}{|c|c|c|c|}
\hline No & Produk (Bungkus) & Desember 2018 & Januari 2019 \\
\hline 1 & Ukuran Lebar $(11,5 \mathrm{~cm} \times 8,5 \mathrm{~cm})$ & 11.600 & 11.200 \\
\hline 2 & Ukuran Panjang $(14,5 \mathrm{~cm} \times 6,5 \mathrm{~cm})$ & 5.800 & 5.040 \\
\hline 3 & Ukuran Kecil $(11,5 \mathrm{~cm} \times 5,5 \mathrm{~cm})$ & 2.900 & 1.960 \\
\hline 4 & Ukuran Bulat $(\varnothing 4,5 \mathrm{~cm}, \mathrm{p}: 15 \mathrm{~cm})$ & 0 & 1.400 \\
\hline & Total & 20.300 & 19.600 \\
\hline
\end{tabular}

Sumber : Diolah dari Data Primer, Tahun 2019

Pada bulan Desember 2018, usaha ini masih belum memproduksi ukuran bulat. Usaha tempe tidak melakukan proses produksi selama satu hari pada Hari Raya Natal dan menghasilkan 20.300 bungkus tempe dalam satu bulan.

Bulan Januari 2019 usaha ini telah ketambahan satu ukuran baru yaitu ukuran bulat. Usaha tempe tidak melakukan proses produksi selama dua hari pada waktu perayaan Tahun Baru dan menghasilkan 19.600 bungkus tempe dalam satu bulan.

\section{Harga Jual}

Harga tempe dijual sesuai dengan ukuran tempe. Untuk ukuran lebar dan panjang, baik yang menggunakan daun maupun yang tidak menggunakan daun yaitu sebesar Rp. 1.000/ bungkus. Ukuran kecil yaitu sebesar Rp. 500/ bungkus sedangkan ukuran bulat yaitu sebesar Rp. 2.000 / bungkus.

\section{Pemasaran Produk \\ Hasil produksi tempe dipasarkan di} berbagai tempat dan sudah memiliki pelanggan tetap seperti Sekolah Polisi Negara (SPN) di Karombasan, beberapa rumah makan di sekitaran tempat usaha, sebagian pedagang tempe di Pasar Bersehati serta konsumen yang langsung datang kerumah usaha tempe. 


\section{Biaya Produksi}

Biaya produksi merupakan semua biaya yang dikeluarkan selama proses produksi pembuatan tempe. Biaya yang dikeluarkan terdiri dari :

\section{A. Biaya Tetap (Fixed Cost)}

Biaya tetap adalah biaya yang tidak berubahrubah atau biaya yang tidak tergantung pada volume produksi. Biaya tetap pada usaha tempe Sumarko terdiri dari biaya listrik, biaya penyusutan alat, biaya sewa tempat usaha dan biaya bunga modal.

a) Biaya Listrik

Pemilik usaha membagi penggunaan biaya listrik untuk rumah tangga sebesar 90\%, sedangkan pemakaian untuk usaha tempe sebesar $10 \%$. Biaya listrik untuk usaha tempe hanya digunakan untuk penerangan di tempat usaha selama \pm 8 jam, untuk mendinginkan kedelai dengan kipas angin selama satu sampai dua jam serta menggunakan pompa listrik untuk menampung air yang akan digunakan untuk keperluan usaha tempe. Biaya listrik perbulan secara keseluruhan yaitu sebesar Rp. 350.000. Jadi biaya penggunaan listrik untuk usaha tempe adalah sebesar Rp. 350.000 x 10\% = Rp. 35.000 per bulan.

b) Biaya Penyusutan Alat

Biaya penyusutan alat yaitu nilai penyusutan selama peralatan digunakan. Nilai penyusutan alat per bulan untuk masingmasing alat dapat dilihat pada Tabel 2.

Tabel 2. Nilai Penyusutan Alat per Bulan

\begin{tabular}{llcc}
\hline No & Jenis Peralatan & $\begin{array}{c}\text { Jumlah } \\
\text { (Unit) }\end{array}$ & $\begin{array}{c}\text { Nilai Penyusutan } \\
\text { (Rp) }\end{array}$ \\
\hline 1 & Dandang Besar & 2 & $2.222,22$ \\
2 & Serok Besar & 1 & 950 \\
3 & Ember & 3 & 375 \\
4 & Keranjang Kecil & 8 & 883,33 \\
5 & Keranjang Besar & 2 & 333,33 \\
6 & Drum & 3 & 2.100 \\
7 & Tatakan Kukusan & 2 & 253,33 \\
\hline \multicolumn{2}{c}{ Total } & & $\mathbf{7 . 0 6 7 , 2 2}$
\end{tabular}

Sumber : Diolah dari Data Primer, Tahun 2019

Tabel 2 menunjukkan nilai penyusutan per bulan dari usaha tempe Sumarko. Usaha ini tidak menggunakan mesin sehingga nilai penyusutan terbesar yaitu dandang besar yang digunakan untuk merebus dan mengkukus kedelai yaitu sebesar Rp. 2.222,22 per bulan kemudian diikuti drum yang digunakan untuk mencuci kedelai dengan nilai penyusutan sebesar Rp. 2.100 per bulan dari total nilai penyusutan. c) Biaya Sewa Tempat Usaha

Usaha Tempe Sumarko mengeluarkan biaya sebesar Rp. 1.000.000/ bulan untuk menyewa tempat usaha sebagai lokasi proses produksi.

d) Bunga Modal Usaha

Bunga modal usaha untuk usaha mikro sebesar $17,50 \%$ dalam satu tahun sehingga dalam satu bulan bunga sebesar $\frac{17,50 \%}{12}=$ $1,45 \%$ atau 0,0145 . Dengan modal sebesar Rp. 15.000.000, biaya bunga modal usaha sebesar Rp. 15.000 .000 × $0,0145=\mathrm{Rp}$. 217.500 per bulan.

Tabel 3. Biaya Tetap Usaha Tempe Sumarko per Bulan

\begin{tabular}{clr}
\hline No & \multicolumn{1}{c}{ Jenis Biaya } & \multicolumn{1}{c}{ Jumlah (Rp) } \\
\hline 1 & Biaya Listrik & 35.000 \\
2 & Biaya Penyusutan Alat & $7.067,22$ \\
3 & Biaya Sewa Tempat Usaha & 1.000 .000 \\
4 & Biaya Modal Usaha & 217.500 \\
\hline \multicolumn{2}{c}{ Total } & $\mathbf{1 . 2 5 9 . 5 6 7 , 2 2}$ \\
\hline
\end{tabular}

Sumber : Diolah dari Data Primer, Tahun 2019

Tabel 3 menunjukkan bahwa biaya tetap terbesar yang dikeluarkan usaha tempe Sumarko dalam satu bulan adalah biaya untuk sewa tempat usaha yaitu sebesar Rp. 1.000.000 dan biaya terkecil adalah biaya penyusutan alat sebesar Rp. $7.067,22$ per bulan karena usaha ini dalam proses berproduksi masih menggunakan cara tradisional dan tidak menggunakan mesin.

\section{B. Biaya Variabel (Variabel Cost)}

Biaya variabel adalah biaya yang berubahrubah atau tergantung pada volume produksi usaha. Biaya variabel pada usaha tempe Sumarko terdiri dari biaya bahan baku, biaya bahan penolong, biaya bahan bakar, biaya pengemasan dan biaya transportasi.

a) Biaya Bahan Baku

Bahan baku untuk pembuatan tempe yang digunakan adalah kedelai. Setiap bulan usaha tempe Sumarko membeli kedelai impor dari luar negeri pada distributor yang sudah menjadi langganan usaha tempe. Bahan baku dibeli satu ton setiap satu bulan.

Tabel 4. Biaya Bahan Baku Bulan Desember 2018 dan Januari 2019

\begin{tabular}{crr}
\hline Bulan Produksi & Desember 2018 & Januari 2019 \\
\hline Jumlah Pembelian (Kg) & 1.000 & 1.000 \\
Harga Bahan Baku per & 8.200 & 7.900 \\
Kg (Rp) & & \\
\hline Biaya (Rp) & $\mathbf{8 . 2 0 0 . 0 0 0}$ & $\mathbf{7 . 9 0 0 . 0 0 0}$ \\
\hline Sumbr:
\end{tabular}

Sumber : Diolah dari Data Primer, Tahun 2019

Tabel 4 menunjukkan bahwa adanya perbedaan harga kedelai per kilogram, pada bulan Desember 2018 harga kedelai sebesar Rp. 8.200/ 
kg sedangkan untuk bulan Januari 2019 harga kedelai sebesar Rp. 7.900/ kg.

b) Biaya Bahan Penolong

Bahan penolong yang digunakan dalam pembuatan tempe adalah tepung beras putih dan ragi tempe. Dalam satu kali pembelian tepung beras putih dan ragi tempe bisa digunakan dalam satu sampai dua bulan.

Harga tepung beras putih sebesar Rp. 7.000/ $\mathrm{kg}$ dan harga ragi tempe 500gr sebesar Rp. 15.000. Tepung beras putih di beli sebanyak dua bungkus atau setara dengan dua kilogram dan ragi tempe di beli sebanyak satu bungkus dengan berat lima ratus gram dalam satu bulan. Maka biaya bahan penolong dalam pembuatan tempe adalah sebesar Rp. 14.000 + Rp. $15.000=$ Rp. 29.000 .

c) Biaya Bahan Bakar

Bahan bakar yang digunakan masih bahan bakar tradisional yaitu kayu bakar. Kayu bakar dibeli satu kali untuk pemakaian dua bulan. Harga kayu bakar sebesar Rp. 200.000 dalam muatan 1 truk besar. Sehingga biaya bahan bakar dalam satu bulan adalah sebesar Rp. 100.000.

d) Biaya Pengemasan

Biaya pengemasan yang dikeluarkan untuk produk tempe adalah biaya yang digunakan untuk membeli plastik dan daun serta minyak tanah untuk lampu botol. Plastik dibeli secara bersamaan dan dihitung menurut berat yang dibeli. Usaha tempe Sumarko membeli plastik sebesar satu kilogram dengan harga Rp. 35.000 untuk pemakaian \pm 5 hari. Daun juga tidak di beli dalam skala besar karena pemakaiannya terbatas sesuai dengan permintaan konsumen. Pemilik membeli daun sebesar satu ikat daun dengan harga Rp. 10.000 untuk pemakaian \pm 3 hari. Minyak tanah untuk lampu botol sebesar 1,5 liter seharga Rp. 25.000 untuk pemakaian 7 hari.

Tabel 5. Biaya Pengemasan per Bulan

\begin{tabular}{ccc}
\hline Jenis Bahan & $\begin{array}{c}\text { Pembelian Kembali } \\
\text { dalam 1 Bulan }\end{array}$ & Biaya (Rp) \\
\hline Plastik (1 kg) & 6 & 210.000 \\
Daun (1 Ikat) & 10 & 100.000 \\
Minyak Tanah (1,5 L) & 4,2 & 105.000 \\
\hline Total & $\mathbf{4 1 5 . 0 0 0}$ \\
\hline Sumber : Diolah dari Data Primer, Tahun 2019 &
\end{tabular}

Tabel 5 menunjukkan bahwa dalam satu bulan produksi plastik untuk pengemasan dibeli sebanyak 6 kali dengan biaya Rp. 210.000 per bulan, daun dibeli 10 kali dengan biaya $\mathrm{Rp}$. 100.000 per bulan serta minyak tanah untuk lampu botol dibeli 3 kali dengan biaya $\mathrm{Rp}$. 105.000 per bulan.

Untuk pengeluaran biaya pengemasan dalam bulan Desember 2019 dan Januari 2019 sama yaitu sebesar Rp. 415.000.

e) Biaya Transportasi

Untuk memasarkan hasil produksi tempe, pemilik usaha memilih untuk menggunakan jasa ojek. Biaya dalam satu hari pengantaran ke tempat yang akan di pasarkan sebesar Rp. 20.000. Dalam satu bulan biaya yang dikeluarkan untuk biaya transportasi adalah Rp. $20.000 \times 30=\mathrm{Rp}$. 600.000 .

f) Biaya Tenaga Kerja

Tenaga kerja di usaha tempe Sumarko berjumlah 3 orang dengan upah yang dibayarkan per hari Rp. 50.000 per orang dengan jam kerja selama \pm 8 jam per hari. Besar biaya tenaga kerja untuk satu bulan adalah Rp. 150.000 x $30=$ Rp. 4.500.000.

Tabel 6. Biaya Variabel Bulan Desember 2018 dan Januari 2019

\begin{tabular}{clrr}
\hline No & Jenis Biaya & Desember 2018 & Januari 2019 \\
\hline 1 & Biaya Bahan Baku & 8.200 .000 & 7.900 .000 \\
2 & Biaya Bahan Penolong & 29.000 & 29.000 \\
3 & Biaya Bahan Bakar & 100.000 & 100.000 \\
4 & Biaya Pengemasan & 415.000 & 415.000 \\
5 & Biaya Transportasi & 600.000 & 600.000 \\
6 & Biaya Tenaga Kerja & 4.500 .000 & 4.500 .000 \\
\hline & Total & $\mathbf{1 3 . 8 4 4 . 0 0 0}$ & $\mathbf{1 3 . 5 4 4 . 0 0 0}$ \\
\hline
\end{tabular}

Tabel 6 menunjukkan biaya variabel yang dikeluarkan bulan Desember 2018 dan Januari 2019 berbeda sebesar Rp. 300.000. Hal ini karena biaya bahan baku yang menurun sebesar Rp. 300 pada bulan Januari 2019 mengikuti naiknya nilai tukar rupiah terhadap dolar Amerika.

\section{Biaya Total (Total Cost)}

Biaya total adalah semua biaya yang digunakan dalam usaha pembuatan tempe meliputi total biaya tetap dan total biaya variabel. Besar biaya total yang dikeluarkan dapat dilihat pada Tabel 7.

\begin{tabular}{ccr} 
Tabel 7. Biaya Total Usaha Tempe Sumarko & \\
\hline Komponen Biaya & Desember 2018 & Januari 2019 \\
\hline Biaya Tetap & $1.259 .567,22$ & $1.259 .567,22$ \\
Biaya Variabel & 13.844 .000 & 13.544 .000 \\
\hline Total & $\mathbf{1 5 . 1 0 3 . 5 6 7 , 2 2}$ & $\mathbf{1 4 . 8 0 3 . 5 6 7 , 2 2}$ \\
\hline
\end{tabular}

Sumber : Diolah dari Data Primer, Tahun 2019 
Tabel 7 menunjukkan bahwa adanya perbedaan besar biaya total pada bulan Desember 2018 dan bulan Januari 2019 disebabkan oleh penurunan harga bahan baku dalam biaya variabel pada bulan Januari 2019 sehingga biaya total yang dikeluarkan pada bulan Desember 2018 lebih besar Rp. 300.000 dari pada biaya total yang dikeluarkan pada bulan Januari 2019.

\section{Penerimaan}

Penerimaan merupakan perkalian antara produksi tempe yang dijual dengan harga tempe perukuran. Penerimaan untuk bulan Desember 2018 dan Januari 2019 dapat dilihat pada Tabel 8.

\begin{tabular}{lccccc}
\multicolumn{6}{l}{ Tabel 8. Penerimaan pada Bulan Desember 2018 dan Januari 2019 } \\
\hline \multirow{2}{*}{$\begin{array}{c}\text { Ukuran } \\
\text { Tempe }\end{array}$} & Harga (Rp) & \multicolumn{2}{c}{ Produksi (Bungkus) } & \multicolumn{2}{c}{ Penerimaan (Rp) } \\
\cline { 3 - 6 } & & Desember & Januari & Desember & Januari \\
& $\mathbf{2 0 1 8}$ & $\mathbf{2 0 1 9}$ & $\mathbf{2 0 1 8}$ & $\mathbf{2 0 1 9}$ \\
\hline Ukuran Lebar & 1.000 & 11.600 & 11.200 & 11.600 .000 & 11.200 .000 \\
Ukuran Panjang & 1.000 & 5.800 & 5.040 & 5.800 .000 & 5.040 .000 \\
Ukuran Kecil & 500 & 2.900 & 1.960 & 1.450 .000 & 980.000 \\
Ukuran Bulat & 2.000 & 0 & 1.400 & 0 & 2.800 .000 \\
\hline \multicolumn{7}{c}{ Total } & $\mathbf{2 0 . 3 0 0}$ & $\mathbf{1 9 . 6 0 0}$ & $\mathbf{1 8 . 8 5 0 . 0 0 0}$ & $\mathbf{2 0 . 0 2 0 . 0 0 0}$ \\
\hline Sumber : Diolah dari Data Primer, Tahun 2019 & & &
\end{tabular}

Tabel 8 menunjukkan bahwa penerimaan pada bulan Januari 2019 mengalami peningkatan dari bulan Desember 2018 meskipun usaha ini tidak melakukan proses produksi selama dua hari. Hal ini bisa terjadi karena usaha ini menambah produk dengan ukuran baru yaitu ukuran bulat dengan harga Rp. 2000 yang meningkatkan penerimaan secara signifikan. Ukuran kecil memiliki volume produksi yang lebih besar namun ukuran bulat memberikan hasil penerimaan lebih dari dua kali lipat karena memiliki harga yang lebih tinggi.

\section{Keuntungan}

Keuntungan yang diterima Usaha Tempe Sumarko dalam satu bulan merupakan selisih dari penerimaan penjualan jumlah tempe yang di produksi sesuai harga ukuran yang ada dan dikurangi dengan biaya-biaya yang dikeluarkan dalam proses produksi yaitu biaya tetap (fixed cost) dan biaya variabel (variabel cost). Sesuai dengan tujuan penelitian untuk menganalisis berapa besar keuntungan yang diperoleh Usaha Tempe
Sumarko, maka akan dilakukan analisis keuntungan berdasarkan hasil penjualan tempe dikurangi dengan semua biaya yang dikeluarkan pada bulan Desember 2018 dan Januari 2019.

Tabel 9. Keuntungan Usaha Tempe Sumarko Bulan Desember 2018 dan Januari 2019

\begin{tabular}{lcr}
\hline Komponen Biaya & Desember 2018 & Januari 2019 \\
\hline Penerimaan (Rp) & 18.850 .000 & 20.020 .000 \\
Biaya Total (Rp) & $15.103 .567,22$ & $14.803 .567,22$ \\
\hline Keuntungan & $\mathbf{3 . 7 4 6 . 4 3 2 , 7 8}$ & $\mathbf{5 . 2 1 6 . 4 3 2 , 7 8}$ \\
\hline Sumber : Diolah dari Data Primer, Tahun 2019 &
\end{tabular}

Tabel 9 menunjukkan bahwa keuntungan pada bulan Januari 2019 lebih besar dari pada bulan Desember 2018, selain karena faktor penerimaan yang diterima lebih besar tetapi juga karena harga yang di keluarkan lebih sedikit. Hal ini disebabkan oleh fluktuasi harga bahan baku kedelai sehingga salah satu faktor penyebab besar-kecilnya keuntungan usaha ini juga tergantung kepada harga kedelai.

\section{Analisis Revenue Cost Ratio (R/C)}

Tingkat keuntungan Usaha Tempe Sumarko dapat dihitung dengan menggunakan analisis Revenue Cost Ratio. Analisis ini merupakan perbandingan antara total penerimaan dan total biaya, dimana :

$\mathrm{R} / \mathrm{C}<1$, berarti usaha mengalami kerugian $\mathrm{R} / \mathrm{C}=1$, berarti usaha tidak menguntungkan dan tidak merugikan

$\mathrm{R} / \mathrm{C}>1$, berarti usaha menerima keuntungan

Nilai R/C Usaha Tempe Sumarko pada bulan Desember 2018 dan Januari 2019 dapat dilihat pada Tabel 10 .

Tabel 10. Revenue Cost Ratio Usaha Tempe Sumarko Bulan Desember 2018 dan Januari 2019

\begin{tabular}{ccc}
\hline No & \multicolumn{1}{c}{ Keterangan } & Nilai R/C \\
\hline 1 & Desember 2018 & 1,24 \\
2 & Januari 2019 & 1,35 \\
\hline \multicolumn{2}{l}{ Sumber : Diolah dari Data Primer, Tahun 2019}
\end{tabular}

Berdasarkan Tabel 10 nilai rata-rata $\mathrm{R} / \mathrm{C}$ untuk Usaha Tempe Sumarko pada bulan Desember yaitu sebesar 1,24 dan pada bulan Januari 2019 memiliki rata-rata rasio $\mathrm{R} / \mathrm{C}$ sebesar 1,35 . Nilai rata-rata $\mathrm{R} / \mathrm{C}$ dari produksi tempe untuk bulan Desember 2018 dan Januari 2019 menunjukkan angka >1, maka dapat disimpulkan bahwa usaha ini menguntungkan. 


\section{KESIMPULAN DAN SARAN}

\section{Kesimpulan}

Berdasarkan hasil penelitian dan analisis yang telah dilakukan maka dapat disimpulkan bahwa Usaha Tempe Sumarko menguntungkan. Keuntungan usaha tempe pada bulan Desember 2018 sebesar Rp. 3.746.432,78 dengan nilai $\mathrm{R} / \mathrm{C}$ ratio yang $>1$ yaitu sebesar 1,24 dan pada bulan Januari 2019 memiliki keuntungan sebesar Rp. 5.216.432,78 dengan nilai $\mathrm{R} / \mathrm{C}$ ratio yang $>1$ yaitu sebesar 1,35. Penambahan ukuran baru yaitu ukuran bulat dengan harga sebesar Rp. 2000 pada bulan Januari 2019 juga menghasilkan kenaikan keuntungan yang cukup signifikan karena harga ukuran bulat yang lebih tinggi dibandingkan dengan ukuran lainnya.

\section{Saran}

Perlu dipertimbangkan untuk pengurangan produksi ukuran kecil dengan harga Rp. 500 yang tidak memberikan keuntungan untuk pengusaha. Penambahan volume produksi untuk ukuran bulat juga sangat disarankan karena memberikan penerimaan yang besar untuk usaha tempe.

Penulis juga menyarankan untuk terus memproses pembuatan izin dan label untuk usaha ini dan ketika nanti telah mendapat izin untuk terus memperpanjang izin dari usaha tempe Sumarko sehingga produk dapat dijual di supermarket dan dapat melebarkan pasar untuk penjualan tempe serta mendapatkan konsumen-konsumen baru diluar pelanggan tetap tempe Sumarko.

\section{DAFTAR PUSTAKA}

Sarfan. 2016. Analisis Keuntungan dan Kelayakan Usaha Pembuatan Tahu di Kelurahan Liabuku Kecamatan Bungi Kota Bau-Bau (Studi Kasus Pada Industri Tahu Mekar). Skripsi. Universitas Halu Oleo

Sudaryanto dan Swastika. 2007. Ekonomi Kedelai di Indonesia. http:// balitkabi. litbang. pertanian.go.id /wpcontent/ uploads/ 2016/ 03/ dele_1. tahlim-1.pdf (diakses 6 Desember 2018)
Udayana. 2011. Peran Agroindustri dalam Pembangunan Pertanian. http:// repository. warmadewa. ac.id/ 29/1/ 1837-1-PB.pdf (diakses pada 6 Desember 2018).

Wardani, C. 2008. Analisis Usaha Pembuatan Tempe Kedelai Di Kabupaten Purworejo. Skripsi. Universitas Sebelas Maret. 